\title{
Effects of ghrelin, leptin and melatonin on the levels of reactive oxygen species, antioxidant enzyme activity and viability of the HCT 116 human colorectal carcinoma cell line
}

\author{
RAFAŁ JAKUB BUŁDAK ${ }^{1}$, KATARZYNA PILC-GUMUŁA ${ }^{1}$, ŁUKASZ BUŁDAK ${ }^{2}$, DARIA WITKOWSKA ${ }^{1}$, \\ MICHAŁ KUKLA ${ }^{3}$, RENATA POLANIAK ${ }^{4}$ and KRYSTYNA ZWIRSKA-KORCZALA ${ }^{1}$
}

\begin{abstract}
${ }^{1}$ Department of Physiology, School of Medicine with the Division of Dentistry, Medical University of Silesia, Zabrze 41-808; Departments of ${ }^{2}$ Internal Medicine and Clinical Pharmacology, and ${ }^{3}$ Gastroenterology and Hepatology, School of Medicine, Medical University of Silesia, Katowice 40-752; ${ }^{4}$ Department of Human Nutrition, School of Public Health, Medical University of Silesia, Bytom 41-902, Poland
\end{abstract}

Received May 27, 2014; Accepted March 9, 2015

DOI: $10.3892 / \mathrm{mmr} .2015 .3599$

\begin{abstract}
Obesity is associated with an increased risk of certain types of cancer, including colon cancer. Adipose tissue is an endocrine organ that produces biologically active substances, such as leptin and ghrelin. Recent research has suggested that adipose-derived hormones may be associated with mechanisms linked to tumorigenesis and cancer progression. Furthermore, previous studies have demonstrated that pineal gland-derived melatonin possesses important oncostatic and antioxidant properties. The present study aimed to determine the effects of the adipokines ghrelin and leptin, and the melatonin on intracellular levels of reactive oxygen species (ROS) and the activity of selected antioxidant enzymes, such as superoxide dismutase, catalase (CAT) and glutathione peroxidase. The effects of these compounds were also determined on the viability of HCT 116 human colorectal carcinoma cells in vitro. The pro-oxidant and growth inhibitory effects of melatonin resulted in an accumulation of ROS and decreased antioxidant capacity in melatonin-treated cells. Ghrelin administration alone caused a significant decrease in the levels of ROS, due to an increased activity of CAT in the HCT 116 cells. In addition, the present study observed increased lipid peroxidation following melatonin treatment, and decreased levels of malondialdehyde following ghrelin or leptin treatment. In conclusion, ghrelin, leptin and melatonin have various influences on the antioxidant capacity of HCT 116 cells. Compared with the adipokines, treatment with melatonin increased ROS levels and decreased cellular viability.
\end{abstract}

Correspondence to: Dr Rafał Jakub Bułdak, Department of Physiology, School of Medicine with the Division of Dentistry, Medical University of Silesia, 19 Jordana Street, Zabrze 41-808, Poland

E-mail: rbuldak@sum.edu.pl

Key words: ghrelin, leptin, melatonin, reactive oxygen species, antioxidant enzymes, lipid peroxidation

\section{Introduction}

Obesity is an increasing public health problem worldwide, which is correlated with an increased risk of certain types of cancer, including breast, colon and prostate cancer (1). The underlying mechanisms regarding the increased cancer risk as a result of obesity are currently unclear. Obese individuals have an increased risk of developing cancer, as compared with normal weight individuals (2). In patients with cancer, oxidative stress may take place either at the onset of disease or as a function of disease progression (3). Adipose tissue is an endocrine organ that produces biologically active substances, including leptin, ghrelin, vaspin, visfatin, resistin and adiponectin (4). Recent studies have suggested that adipose-derived hormones and cytokines, termed adipokines, such as leptin, adiponectin and inflammatory markers, may be associated with mechanisms linked to tumorigenesis (2).

Ghrelin has been identified as a hormone that is a natural ligand of the orphan growth hormone secretagogue (GHS) receptor type 1a (GHS-R1a) (5). Ghrelin is a unique acylated 28-amino acid peptide, which is produced and secreted by the X/A-like cells of the oxyntic glands of the stomach. Ghrelin stimulates growth hormone $(\mathrm{GH})$ secretion, gastric motility, food intake, gastric acid secretion, modulation of pancreatic exocrine and endocrine functions, and modulation of the proliferation of neoplastic cells, as well as exhibiting effects on the immune system (6-8). Two major molecular forms of ghrelin are found in the stomach and plasma: Acylated and deacylated ghrelin (9). Ghrelin is commonly expressed in various organs. The highest levels of ghrelin are found in the small intestine, pancreatic islet cells, gallbladder, liver, spleen and immune cells (10). Recent evidence has demonstrated that ghrelin has dual proliferative effects, according to the type of cell or tissue, via mechanisms that are dependent on or independent of GHS-R1a (11). In addition, ghrelin has possible antioxidant and anti-inflammatory effects $(7,12)$. Ghrelin exhibits a strong gastroprotective role, at least in part due to its anti-inflammatory actions (13). The marked gastroprotective effects of ghrelin are supposedly derived from its antioxidant properties (7). An 
in vitro study of human polymorphonuclear cells incubated with ghrelin demonstrated that ghrelin was able to inhibit the generation of reactive oxygen species (ROS), as measured by chemiluminescence. The mechanism by which ghrelin inhibits ROS may be through the blockade of enzymes required for their production (14).

Leptin (OB protein) is a 167-amino acid peptide hormone that regulates food intake and energy balance. Leptin is a protein product of the ob gene, which is mainly expressed in adipose tissue, with receptors located in the central nervous system and in peripheral tissue (15). ObRb is the main isoform of the leptin receptor, which is expressed by colonocytes and has been shown to be preserved in human colonic adenomas and carcinomas (16). Leptin promotes body weight loss by acting on the brain, in order to decrease food intake and increase sympathetic nervous system activity (17). The antioxidant enzymes catalase (CAT) and glutathione peroxidase (GSH-Px) are known to be lower in ob/ob mice, and leptin treatment is able to correct these alterations (18). Recent studies have suggested that leptin may be associated with mechanisms underlying tumorigenesis and cancer progression (19-21).

Melatonin (N-acetyl-5-methoxytryptamine) is a pineal hormone with structural similarities to 5-hydroxytryptamine. Melatonin is able to act via MT1, MT2 and MT3 membrane receptors, and the retinoid nuclear receptor RZR/ROR (22). Melatonin is capable of reducing free radical damage by acting directly as a free radical scavenger, and indirectly, by stimulating the activities of antioxidant enzymes (23). In addition, melatonin protects against lipid peroxidation and decreases the synthesis of malondialdehyde (MDA), which is an end-product of lipid peroxidation in non-cancerous cells $(24,25)$. Numerous studies have demonstrated that melatonin has important oncostatic properties (26-29). It has been demonstrated that melatonin inhibits cell proliferation in various cancer cell lines, including human B-lymphoma cells, HL-60 human myeloid leukemia cells and human neuroblastoma cancer cells (27). Fan et al (27) suggested that chemotherapy combined with melatonin may increase the therapeutic effects of anticancer drugs. In addition, Osseni et al (28) previously demonstrated that melatonin can act as an antioxidant and pro-oxidant on a human liver cell line, depending on the concentration and the duration of incubation. Normal human cells produce minimal amounts of ROS, which are reduced by antioxidant enzymes and low molecular weight radical scavengers; however, the blood levels of ROS are significantly higher in patients with cancer, as compared with healthy donors (3).

The present study aimed to determine the effects of the adipokines ghrelin and leptin, and the melatonin, on intracellular ROS levels and the activity of selected antioxidant enzymes: Superoxide dismutase (SOD), CAT and glutathione peroxidase (GSH-Px). In addition, the effects of these adipokines and melatonin were determined on the viability of HCT 116 human colorectal carcinoma cells in vitro.

\section{Materials and methods}

Cell culture. The HCT 116 human colorectal carcinoma cell line was obtained from the Silesian University of Technology, (Gilwice, Poland) as a gift from Dr M. Skonieczna. The cells were plated at a density of $5 \times 10^{5}$ cells per dish $\left(10 \mathrm{~cm}^{2}\right)$ and were cultured in McCoy's 5A modified medium (Sigma-Aldrich, St. Louis, MO, USA) supplemented with $10 \%$ fetal bovine serum (FBS; BioWhittaker ${ }^{\mathrm{TM}}$, Lonza, Verviers, Belgium), $100 \mathrm{U} / \mathrm{ml}$ penicillin and $0.1 \mathrm{mg} / \mathrm{ml}$ streptomycin (BioWhittaker $\left.{ }^{\mathrm{TM}}\right)$, at $37^{\circ} \mathrm{C}$ in an atmosphere containing $95 \%$ air and $5 \% \mathrm{CO}_{2}$. The HCT 116 cell line was free of mycoplasma, pathogenic viruses and bacteria. BacT/ALERT ${ }^{\circledR} 3 \mathrm{D}$ automated microbial detection system was used to assess microbial contamination of the culture medium (bio-Mérieux, Marcy l'Etoile, France). Mycoplasma species identification were made using ELISA assay with commercial diagnostic Mycoplasma detection kit (Roche, Mannheim, Germany), according to the manufacturer's instructions. The kit contains species-specific polyclonal antibodies to Acholeplasma laidlawii, Mycoplasma arginini, $M$. hyorhinis and $M$. orale. The cell cultures were maintained for no longer than 4 weeks after recovery from the frozen stock.

Experimental protocol. Cell cultures with or without ghrelin $\left(10^{-8} \mathrm{M}\right)$, leptin $\left(10^{-6} \mathrm{M}\right)$ and melatonin $\left(10^{-6} \mathrm{M}\right)$ (all Sigma-Aldrich) were incubated for $24 \mathrm{~h}$. The substances were applied separately in ROS and antioxidant enzyme assays. Melatonin was dissolved in a minimum amount of ethanol $(95 \%)$, and then diluted with the aforementioned medium, in order to reach the final concentration of $10^{-6} \mathrm{M}$. An equivalent quantity of ethanol (95\%) was added to the control cells, and all remaining studied groups treated solely with ghrelin or leptin. Leptin and ghrelin were dissolved in growth medium to reach the final concentrations of $10^{-6} \mathrm{M}$ and $10^{-8} \mathrm{M}$, respectively. Incubation media were not changed during this time. Following the incubation period, the cell supernatants were removed, centrifuged and maintained at $-80^{\circ} \mathrm{C}$ until further use.

Intracellular ROS detection. Intracellular ROS levels were detected in 2', 7'-dichlorodihydrofluorescein diacetate $\left(\mathrm{H}_{2} \mathrm{DCF}-\mathrm{DA}\right)$-loaded cells (Molecular Probe, Leiden, Netherlands) using a fluorescent measurement system (Astroscan Cytofluor 2300/2350, Millipore, Billerica, MA, USA). HCT-116 cells $\left(2 \times 10^{6}\right)$, untreated or treated with ghrelin, leptin or melatonin for $24 \mathrm{~h}$, were plated in Corning six-well plates (Sigma-Aldrich) and were pre-incubated with $5 \mu \mathrm{M}$ $\mathrm{H}_{2} \mathrm{DCF}-\mathrm{DA}$ for $1 \mathrm{~h}$ at $37^{\circ} \mathrm{C}$. The plates were then centrifuged at $250 \mathrm{x} \mathrm{g}$ for $10 \mathrm{~min}$, and the fluorescence of the control and treated cells was measured using a Cytofluor reader (excitation at $504 \mathrm{~nm}$, emission at $526 \mathrm{~nm}$ ). The background of deacetylated, oxidized DCF (2', 7'-dichlorofluorescein) was 65-85 relative fluorescent units (R.F.U.) $(30,31)$.

Enzymatic assays. Following exposure of the cultured cells to melatonin $\left(10^{-6} \mathrm{M}\right)$, ghrelin $\left(10^{-8} \mathrm{M}\right)$ or leptin $\left(10^{-6} \mathrm{M}\right)$ for $24 \mathrm{~h}$, the antioxidative enzyme activity of MnSOD, CuZnSOD, GSH-Px and CAT, and the levels of MDA were measured in the cell supernatants.

The method of Paglia and Valentine (32) was used to determine GSH-Px activity with minor modifications (33). Briefly, the HCT 116 cells were pooled to a density of $5 \times 10^{6}$ cells $/ \mu 1$. Following centrifugation at $600 \mathrm{x}$ g for $5 \mathrm{mins}$, the cell pellet was mixed with $200 \mu \mathrm{l}$ cell lysis buffer, containing $2.5 \mathrm{M} \mathrm{NaCl}$, $100 \mathrm{mM} \mathrm{Na}$-EDTA, $10 \mathrm{mM}$ Tris- $\mathrm{HCl}, 1 \%$ Triton $\mathrm{X}-100$ (POCH, Gliwice, Poland) and sonicated for $10 \mathrm{sec}$. Cell lysates 
were obtained by centrifugation at $17,000 \mathrm{x} \mathrm{g}$ for $30 \mathrm{~min}$ at $4^{\circ} \mathrm{C}$. The protein concentration was then measured using Bio-Rad protein assay dye reagent (cat.no. 500-0006; Bio-Rad Laboratories, Hercules, CA, USA). Equal volumes of each sample, containing $30 \mu \mathrm{g}$ protein, were mixed with $2.68 \mathrm{ml}$ of $0.05 \mathrm{M}$ phosphate buffer ( $\mathrm{pH} 7.0$ ) supplemented with $0.005 \mathrm{M}$ EDTA. The following solutions were then added sequentially: $100 \mu \mathrm{l}$ of $0.0084 \mathrm{M}$ NADPH (a reduced form of nicotinamide adenine dinucleotide phosphate), $10 \mu \mathrm{l}$ glutathione reductase, $10 \mu \mathrm{l}$ of $1.125 \mathrm{M}$ sodium nitrate, and $100 \mu \mathrm{l}$ of $0.15 \mathrm{M}$ reduced glutathione. The enzymatic reaction was initiated by the addition of $100 \mu \mathrm{l}$ of $0.0022 \mathrm{M} \mathrm{H}_{2} \mathrm{O}_{2}$. The conversion of NADPH to oxidized $\mathrm{NADP}^{+}$was monitored by continuous recording of the absorbance at a wavelength of $340 \mathrm{~nm}$ using a microplate reader (Dynex Technologies, VA, USA), between 2 and 4 min after the initiation of the reaction. The control measurements were recorded in a simultaneous assay, where the sample was replaced with an equal volume of cell lysis buffer One IU GSH-Px enzyme activity is defined as $1 \mathrm{mM}$ NADPH converted to $\mathrm{NADP}^{+}$per mg of protein (IU/mg p.).

The SOD activity assay was conducted based on a procedure described by Paoletti and Mocali (34), with minor modifications (33). The preparation of cell lysates and the measurement of protein concentration were the same as that described prior to the GSH-Px assay. Equal amounts of protein $(30 \mu \mathrm{g})$ from each sample were mixed with $800 \mu \mathrm{l}$ of $1 \mathrm{X}$ triethanolamine-diethanolamine buffer ( $\mathrm{pH} 7.4), 40 \mu \mathrm{l}$ of $7.5 \mathrm{mM}$ NADPH, and $25 \mu \mathrm{l}$ of $100 \mathrm{mM}$ EDTA- $\mathrm{MnCl}_{2}$. The reaction was initiated by the addition of $0.1 \mathrm{ml}$ of $10 \mathrm{mM}$ mercaptoethanol. The decrease in absorbance was measured at a wavelength of $340 \mathrm{~nm}$ over $20 \mathrm{~min}$, at room temperature. The control consisted of a reaction mixture in which the sample was replaced with an equal volume of cell lysis buffer.

For the determination of MnSOD activity, CuZnSOD activity was inhibited by incubating the samples with $5 \mathrm{mM}$ potassium cyanide (KCN) for $30 \mathrm{~min}$. The samples were assayed for MnSOD activity within $2 \mathrm{~h}$ of the addition of KCN. Total specific SOD and MnSOD (following inhibition of CuZnSOD with $\mathrm{KCN}$ ) activity levels were measured, and then $\mathrm{CuZnSOD}$ activity was calculated. The total activity of SOD was detected using methods of Paoletti and Mocali without KCN inhibition, according to absorbance obtained in cell lysates. The activity of MnSOD was calculated by reading the absorbance in cell lysates following treatment with the CuZnSOD inhibitor, KCN. The activity of CuZnSOD was calculated using the formula: CuZnSOD activity = total SOD - MnSOD activity. The enzymatic activity of both SOD isoenzymes was expressed in Nitric Units (NU) per mg of protein (NU/mg p.). One NU represents $50 \%$ inhibition by SOD of the nitrosol ion formation under these conditions.

Catalase (CAT) activity was measured according to the kinetic method of Aebi (35), and was expressed as kIU per $\mathrm{mg}$ of protein ( $\mathrm{kIU} / \mathrm{mg}$ p.). Concentrations of MDA were determined according to the colorimetric method described by Ohkawa et al (36) using a reaction with thiobarbituric acid. Levels of MDA were expressed as $\mu \mathrm{mol}$ MDA per mg of protein ( $\mu \mathrm{mol} \mathrm{MDA} / \mathrm{mg} \mathrm{p}$.)

Assessment of cell viability. Cell viability was evaluated using alamarBlue ${ }^{\circledR}$ reagent (Invitrogen Life Technologies,
Paisley, UK), according to the manufacturer's instructions. The cells were seeded in 96-well culture plates at a density of $1.5 \times 10^{4}$ cells/well. The control cells were incubated in McCoy's 5A medium supplemented with 5\% FBS, whereas the treated cells were treated with ghrelin $\left(10^{-8} \mathrm{M}\right)$, leptin $\left(10^{-6} \mathrm{M}\right)$ or melatonin $\left(10^{-6} \mathrm{M}\right)$, separately or in combination for $24 \mathrm{~h}$. The medium was refreshed daily, with new medium and new test compounds. The alamarBlue ${ }^{\circledR}$ stock solution was aseptically added to the wells, following $24 \mathrm{~h}$ of culture, in amounts equal to $10 \%$ of the incubation volume. Resazurin reduction was determined following a $4 \mathrm{~h}$ incubation by measuring the fluorescence at a wavelength of $560 \mathrm{~nm}$ (excitation)/590 nm (emission), using an Astroscan Cytofluor microplate reader (Millipore).

Statistical analysis. The normality of distribution was evaluated by means of Shapiro-Wilk's test. Data are expressed as the mean \pm standard deviation from four independent experiments, each performed in triplicate $(n=12$; four experiments performed in tripilicate). Statistical analyses were performed using Statistical 7.0 software (Statsoft, Krakow, Poland). The cell viability assay data were analyzed by one-way analysis of variance (ANOVA), followed by Tukey's honestly significant difference multiple range test. For all enzymatic assays, data were analyzed with one-way ANOVA with post-hoc Bonferroni corrections. $\mathrm{P}<0.05$ was considered to indicate a statistically significant difference.

\section{Results}

Effects of ghrelin, leptin and melatonin on ROS levels, antioxidant enzyme activity and MDA levels in HCT-116 cells. Treatment with leptin $\left(10^{-6} \mathrm{M}\right)$ did not affect the production of ROS after $24 \mathrm{~h}$, whereas treatment with melatonin at a $10^{-6} \mathrm{M}$ concentration resulted in increased ROS production by $\sim 60 \%$ in the tested HCT 116 cells, as compared with the control group $(\mathrm{P}<0.05)$. Conversely, administration of ghrelin $\left(10^{-8} \mathrm{M}\right)$ resulted in a decrease in the intracellular levels of ROS by $\sim 20 \%$ in the tested cells, as compared with the untreated cells $(\mathrm{P}<0.05)$. Significant differences were also detected between ROS levels in the HCT 116 cells stimulated solely with ghrelin or melatonin, as compared with all of the remaining studied groups $(\mathrm{P}<0.05)$. The intracellular ROS levels of the HCT 116 cells treated with the various substances are shown in Fig. 1.

The present study also evaluated the activity of selected antioxidant enzymes in HCT 116 cells following treatment with ghrelin, leptin or melatonin. Compared with the control cells, MnSOD activity was significantly higher following treatment with melatonin, ghrelin and leptin by $\sim 52,14$ and $24 \%$, respectively $(\mathrm{P}<0.05$; Fig. $2 \mathrm{~A})$.

Notably, treatment with melatonin alone resulted in a significant decrease in CuZnSOD activity by $\sim 28 \%$, as compared with the control group $(\mathrm{P}<0.05)$. CuZnSOD activity was also $\sim 40 \%$ lower in the melatonin-treated group, as compared with the cells exposed to ghrelin in combination with leptin $(\mathrm{P}<0.05)$. There were no statistically significant differences in $\mathrm{CuZnSOD}$ activity following treatment with ghrelin or leptin, as compared with the untreated cells (Fig. 2B).

No statistically significant differences were detected in GSH-Px activity following treatment with ghrelin or leptin, as 


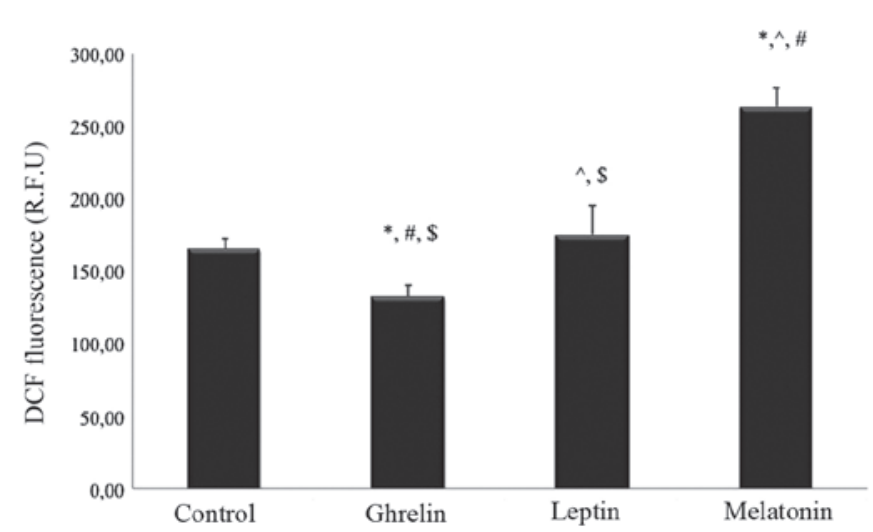

Figure 1. Effects of $24 \mathrm{~h}$ ghrelin $\left(10^{-8} \mathrm{M}\right)$, leptin $\left(10^{-6} \mathrm{M}\right)$ and melatonin $\left(10^{-6} \mathrm{M}\right)$ treatment on the intracellular ROS levels of HCT 116 human colorectal cancer cells. DCF-detectable ROS were measured in all of the study and control (untreated cells) groups. Values are expressed as R.F.U, and were analyzed by one-way analysis of variance with post-hoc Bonferroni correction. Data are expressed as the mean \pm standard deviation $(\mathrm{n}=12)$. ${ }^{*} \mathrm{P}<0.05$, vs. control; ${ }^{\wedge} \mathrm{P}<0.05$, vs. the ghrelin-treated group; ${ }^{\mathrm{P}} \mathrm{P}<0.05$, vs. the leptin-treated group; ${ }^{\$} \mathrm{P}<0.05$, vs. the melatonin-treated group. ROS, reactive oxygen species; DCF, 2', 7'-dichlorofluorescein; R.F.U, relative fluorescent units.
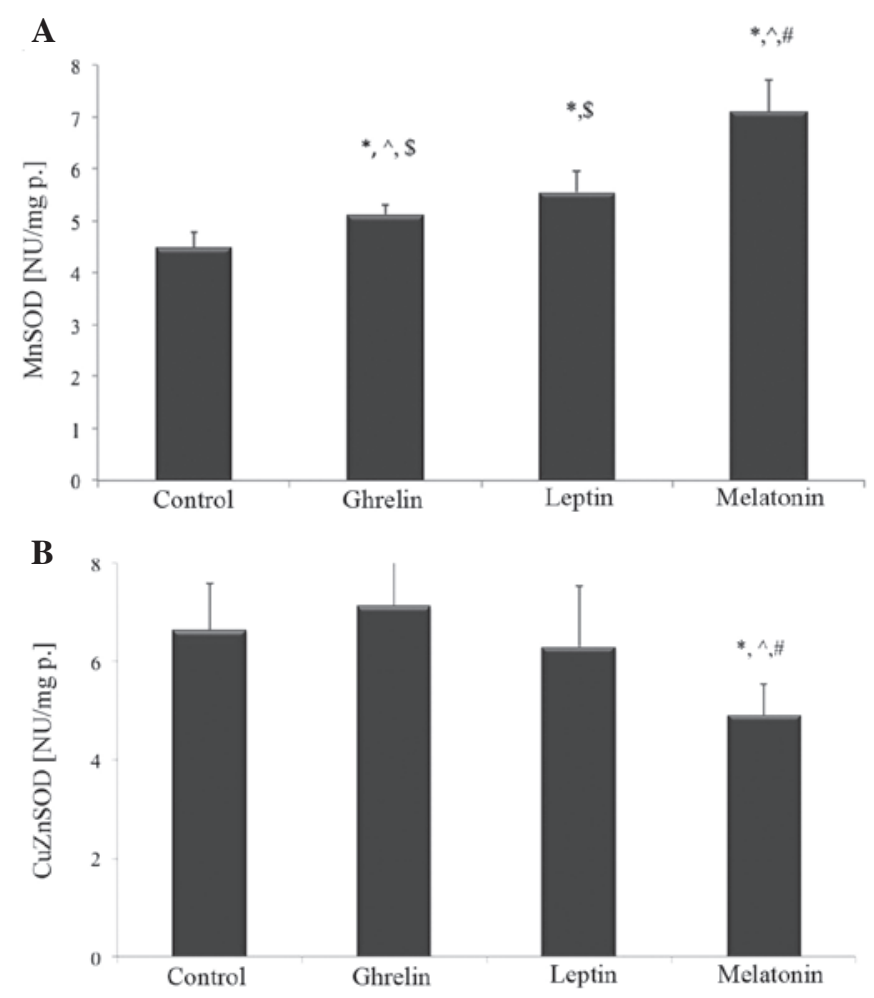

Figure 2. (A) MnSOD and (B) CuZnSOD activity, expressed in NU/mg p., in the cell supernatants of HCT 116 human colorectal carcinoma cells following treatment with ghrelin $\left(10^{-8} \mathrm{M}\right)$, leptin $\left(10^{-6} \mathrm{M}\right)$ and melatonin $\left(10^{-6} \mathrm{M}\right)$ for $24 \mathrm{~h}$. Data represent the means \pm standard deviation $(n=12)$ and were analyzed by one-way analysis of variance with post-hoc Bonferroni correction. ${ }^{*} \mathrm{P}<0.05$, vs. control; ${ }^{\wedge} \mathrm{P}<0.05$, vs. the ghrelin-treated group; ${ }^{\text {}} \mathrm{P}<0.05$, vs. the leptin-treated group; ${ }^{\$} \mathrm{P}<0.05$, vs. the melatonin-treated group. SOD, superoxide dismutase.

compared with the control group. Treatment with melatonin decreased GSH-Px activity by $\sim 3$-times, as compared with the control group $(\mathrm{P}<0.05$; Fig. 3A). Furthermore, incubation with melatonin resulted in decreased CAT activity by $\sim 40 \%$, as compared with the control group $(\mathrm{P}<0.05)$. CAT activity
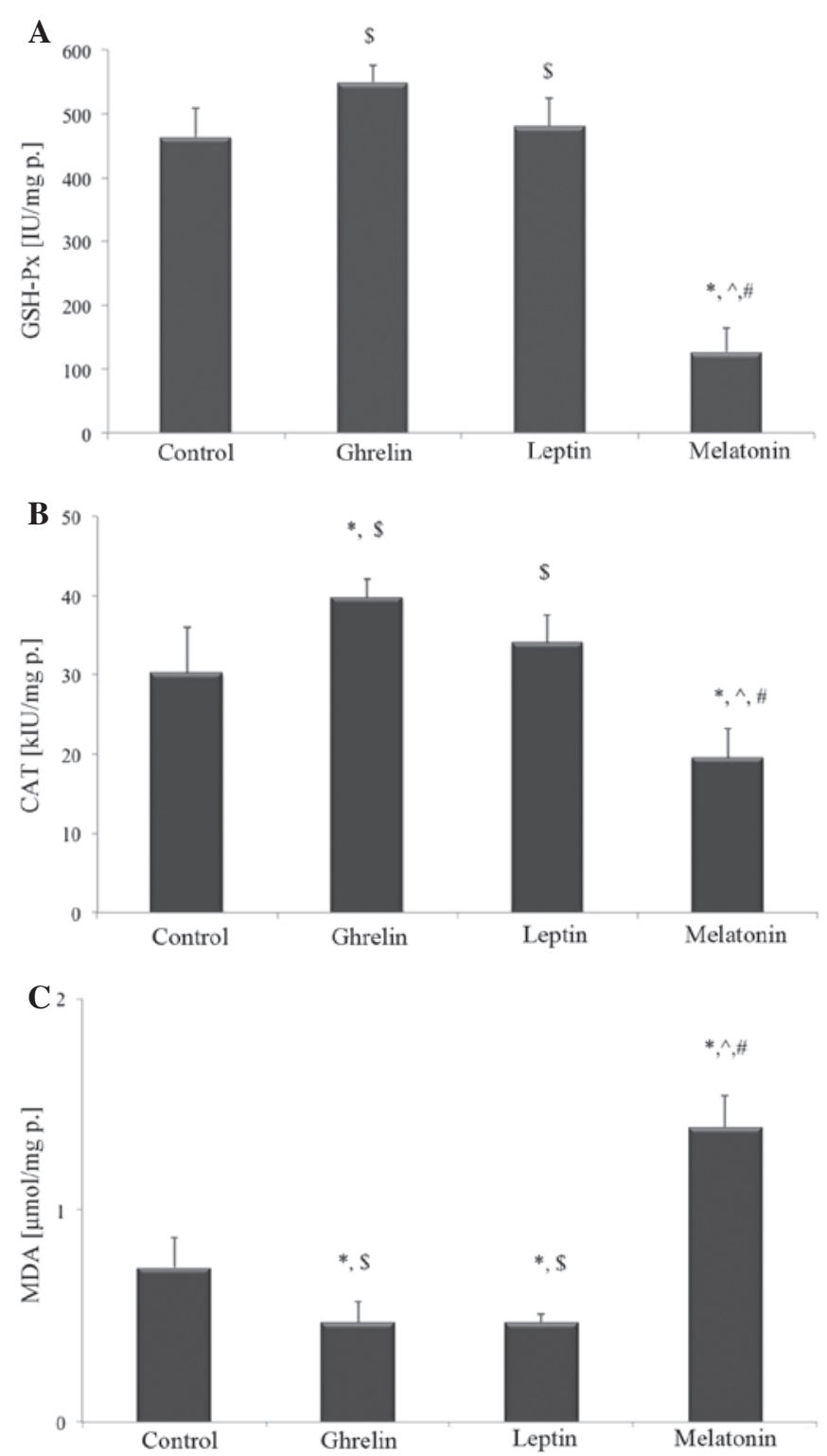

Figure 3. (A) GSH-Px and (B) CAT enzyme activities, and (C) MDA levels in the cell supernatants of HCT 116 human colorectal carcinoma cells following treatment with ghrelin $\left(10^{-8} \mathrm{M}\right)$, leptin $\left(10^{-6} \mathrm{M}\right)$ and melatonin $\left(10^{-6} \mathrm{M}\right)$ for $24 \mathrm{~h}$. Data represent the mean \pm standard deviation $(\mathrm{n}=12)$ and were analyzed by one-way analysis of variance with post-hoc Bonferroni correction. ${ }^{*} \mathrm{P}<0.05$, vs. control; ${ }^{\wedge} \mathrm{P}<0.05$, vs. the ghrelin-treated group; ${ }^{*} \mathrm{P}<0.05$, vs. the leptin-treated group; ${ }^{\$} \mathrm{P}<0.05$, vs. the melatonin-treated group. GSH-Px, glutathione peroxidase; CAT, catalase; MDA, malondialdehyde.

was also decreased, as compared with all of the remaining studied groups $(\mathrm{P}<0.05)$. Conversely, treatment with ghrelin resulted in a significant increase in CAT activity by $\sim 30 \%$, as compared with the untreated cells $(\mathrm{P}<0.05)$. CAT activity was also increased in the HCT 116 cells treated solely with ghrelin, as compared with the melatonin-treated cells $(\mathrm{P}<0.05)$. Leptin administration did not cause any statistically significant changes in CAT activity in the HCT 116 cells, as compared with the control cells (Fig. 3B).

Following 24 hours of treatment, ghrelin and leptin decreased MDA levels by $\sim 38 \%$, as compared with the untreated cells $(\mathrm{P}<0.05)$. MDA levels were $\sim 2$-fold higher in the melatonin-treated cells, as compared with the control cells $(\mathrm{P}<0.05$; Fig. 3C). 


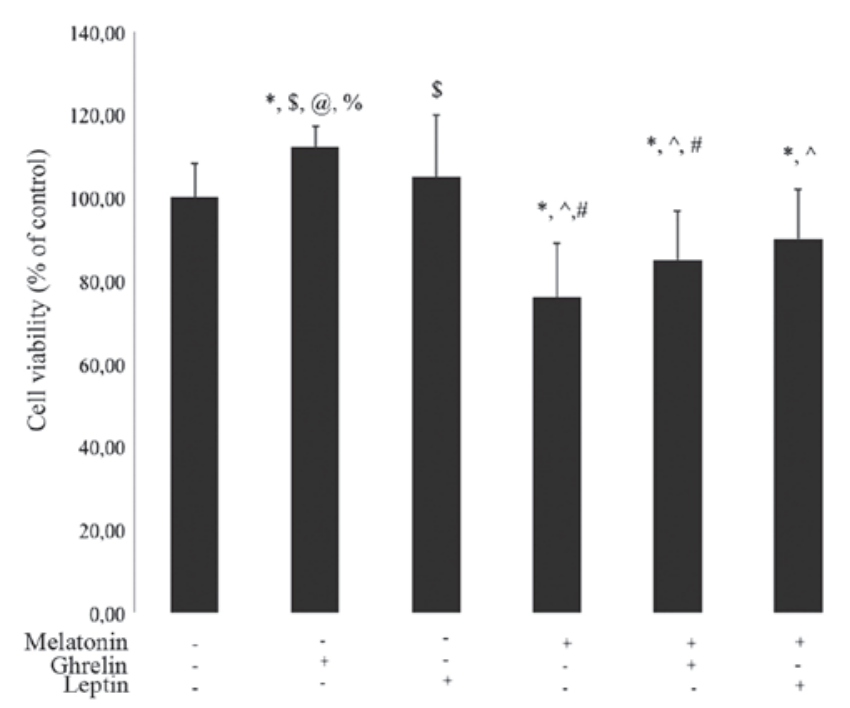

Figure 4. Effects of ghrelin $\left(10^{-8} \mathrm{M}\right)$, leptin $\left(10^{-6} \mathrm{M}\right)$ and melatonin $\left(10^{-6} \mathrm{M}\right)$ treatment on the viability of HCT 116 human colorectal carcinoma cells. The cells were treated with these factors, either alone or in combination, for $24 \mathrm{~h}$ and then analyzed using the alamarBlue ${ }^{\circledR}$ assay. Cell viability of the treated cells was expressed as a mean percentage of the control \pm standard deviation $(n=12)$. Data were analyzed by one-way analysis of variance, followed by Tukey's honestly significant difference multiple range test; ${ }^{*} \mathrm{P}<0.05$, vs. control; ${ }^{\wedge} \mathrm{P}<0.05$, vs. the ghrelin-treated group; ${ }^{~} \mathrm{P}<0.05$, vs. the leptin-treated group; ${ }^{\$} \mathrm{P}<0.05$, vs. the melatonin-treated group; ${ }^{\circledR} \mathrm{P}<0.05$, vs. the melatonin + ghrelin-treated group; ${ }^{\%} \mathrm{P}<0.05$ vs. the melatonin + leptin-treated group.

Effects of ghrelin, leptin and melatonin on HCT 116 cell viability. The growth of HCT 116 cells was determined in response to treatment with melatonin, ghrelin and leptin, either separately or in combination, for $24 \mathrm{~h}$. Cell viability was decreased following treatment with melatonin $\left(10^{-6} \mathrm{M}\right)$ at $24 \mathrm{~h}(76 \%$ of control; $\mathrm{P}<0.05)$. In the group treated with melatonin $\left(10^{-6} \mathrm{M}\right)$ in combination with ghrelin $\left(10^{-8} \mathrm{M}\right)$ the cells also exhibited decreased cell viability, as compared with the control group (85\% of control; $\mathrm{P}<0.05$ ). No statistical differences were observed between the cell viability of HCT 116 cells treated solely with leptin for $24 \mathrm{~h}$, as compared with the control cells. Conversely, ghrelin administration alone $\left(10^{-8} \mathrm{M}\right)$ resulted in a slight increase in cell viability, as compared with the untreated cells ( $112 \%$ of control; P<0.05; Fig. 4). In addition, there was a significant increase in cell viability in the cells treated solely with ghrelin, as compared with the groups treated with the following combinations: Ghrelin + melatonin, and leptin + melatonin $(\mathrm{P}<0.05)$.

\section{Discussion}

Obesity represents a significant risk factor for the development of cancer; however, the mechanisms underlying this association remain to be determined. It has been suggested that certain adipose tissue-derived hormones may significantly influence the growth and proliferation of tumorous stroma and malignant cells (1). Recent evidence has demonstrated that key mechanisms of cancer are linked via endogenous stress-induced DNA damage, which is caused by ROS (37). Oxidative stress induced by a cellular redox imbalance has been detected in various types of cancer cells (38). Certain enzymatic antioxidants, including MnSOD, CuZnSOD, CAT and GSH-Px, are able to remove ROS and prevent oxidative stress.

The present study evaluated the antioxidant enzyme activities, ROS levels and cell viability of human derived colorectal carcinoma HCT 116 cells following treatment with melatonin, ghrelin and leptin.

In obese individuals, serum levels of leptin are markedly increased, and a recent study indicated that leptin is overexpressed in human colorectal cancer, suggesting that leptin may contribute to the development and progression of colorectal cancer (39). The majority of studies have demonstrated that leptin may increase the growth of cancer cells in vitro (40-44). It has also been shown that leptin increases the production of ROS in various cancer cell lines $(45,46)$. Conversely, in the present study, treatment with leptin $\left(10^{-6} \mathrm{M}\right)$ did not affect the production of ROS, and had no effect on HCT 116 cell viability. Lack of ROS overproduction in the present study may be explained by the fact that leptin treatment resulted in increased activity of selected antioxidant enzymes, which are able to remove ROS from the cells. The results of the present study demonstrated that treatment with leptin significantly increased MnSOD activity, and as a result, decreased the concentration of MDA. In the present study, leptin had no effect on the activities of CAT and GSH-Px. However, in our previous findings treatment with leptin $\left(10^{-6} \mathrm{M}\right)$ markedly increased SOD, CAT and GSH-Px activity in 3T3-L1 pre-adipocytes, after $24 \mathrm{~h}$ of exposure. Furthermore, leptin stimulation also failed to influence the cell count of tested cells (47). The dose of leptin used in the present study was able to induce the activity of selected antioxidant enzymes, without altering HCT 116 cell viability. Conversely, Balasubramaniyan et al (48) demonstrated a decrease in viability of HepG2 hepatocellular cancer cells alongside elevated SOD and CAT activity following leptin treatment; however, the dose of leptin in this previous study was $\sim 10$-times greater than in the present study. In the present study, leptin and ghrelin decreased MDA levels in HCT 116 cells. MDA is the end product of the lipid peroxidation process, and the amount of MDA can express the degree of oxidative stress in living cells. The lipid peroxidation process has previously been implicated in the mechanism of carcinogenesis. MDA is mutagenic in bacterial and mammalian cells, and is carcinogenic in rats (38). Our previous findings suggested that another adipose tissue-derived adipokine, visfatin, may be able to trigger redox adaptation responses, leading to an increased antioxidant capacity alongside decreased levels of lipid peroxidation in Me45 melanoma cells. Furthermore, visfatin led to a significantly increased rate of proliferation and viability of Me45 melanoma cells (33).

Ghrelin has been suggested to possess both antioxidant and anti-inflammatory effects $(7,12)$. studies using human polymorphonuclear cells incubated with ghrelin, demonstrated that ghrelin inhibited ROS generation (14). The present study also observed similar ROS depletion ( 20\%) in HCT 116 cells treated with ghrelin. Conversely, Li et al (48) demonstrated that ghrelin did not reduce the levels of intracellular ROS in human endothelial cells treated with $\mathrm{H}_{2} \mathrm{O}_{2}$. This different observation may be explained by variations in experimental design regarding cell type, concentration of ghrelin and duration of incubation, as well as the number of receptors 
activated. In the present study the HCT 116 cells were incubated with ghrelin at a $10^{-8} \mathrm{M}$ concentration. The system used in the present study allowed the measurement of ROS (mainly $\mathrm{H}_{2} \mathrm{O}_{2}$ ) using the oxidant sensitive $\mathrm{H}_{2}$ DCFDA probe, whereas the system used by Li et al (49), measured complete ROS level by chemiluminescence.

The present study also observed a slight increase in HCT 116 cell viability (112\% of control) following treatment with ghrelin $\left(10^{-8} \mathrm{M}\right)$ for $24 \mathrm{~h}$, and this may be due to ROS depletion. Concordant with the results of the present study, Tian and Fan (11) previously demonstrated that the same concentration of ghrelin enhanced the viability of AGS gastric cancer cells in vitro. The pro-proliferative role of ghrelin in AGS cells was accompanied by the increased percentage of cells in $\mathrm{S}$ phase of the cell cycle, as compared with the untreated cells (59.2 vs. 43.2\%, respectively) (11). Both studies suggest that ghrelin may have a role in the development and progression of gastric and colon cancer. The role of ghrelin in the initiation and progression of gastrointestinal cancer requires further investigation.

In the present study ghrelin also significantly increased CAT and MnSOD activity. CAT and MnSOD are endogenous antioxidant enzymes that protect against ROS-induced damage. MnSOD is one of the most important intracellular antioxidant enzymes, and CAT is the most important enzyme that metabolizes exogenous $\mathrm{H}_{2} \mathrm{O}_{2}$ into water and molecular oxygen (10). The significantly decreased capacity of various types of tumor for detoxifying $\mathrm{H}_{2} \mathrm{O}_{2}$ has previously been linked to a decreased level of CAT (50). Similarly, in non-cancerous $\mathrm{H} 9 \mathrm{c} 2$ cardiomyocytes, ghrelin at a $10^{-8} \mathrm{M}$ concentration significantly increased the mRNA expression levels and activity of MnSOD and CAT after $24 \mathrm{~h}$ of incubation (51). Furthermore, the present study demonstrated that ghrelin had no effect on GSH-Px; however, it was able to decrease the concentration of MDA. Kheradmand et al (52) demonstrated that ghrelin was able to enhance SOD activity in an animal model of ovarian cancer; however, it failed to induce overt changes in GSH-Px activity. In addition, ghrelin markedly increased SOD activity, which is a key antioxidant enzyme that targets oxidative damage, in rat ovarian tissue by $>3$-fold, as compared with the control group (52). The findings of the present study were concordant with the results obtained from normal, non-cancerous cells and tissues in other studies $(51,52)$, and suggest that ghrelin may enhance the endogenous antioxidant defense mechanisms through the upregulation of intracellular antioxidant enzymes, including CAT and MnSOD. In the present study, ghrelin protected the HCT 116 cells against oxidative stress and lipid peroxidation.

The results of the present study also demonstrated that melatonin had an effect on antioxidant enzyme activities, ROS levels and HCT 116 cell viability, after a $24 \mathrm{~h}$ incubation. Treatment with melatonin decreased CAT and GSH-Px activity, and increased MDA and ROS levels. Free radical-induced cell damage may be quantitatively assessed by measuring MDA levels, which are an indicator of lipid peroxidation. The present study suggested that melatonin had pro-oxidant properties in HCT 116 cells. Osseni et al (28), was the first to demonstrate that melatonin can have a pro-oxidant effect, depending on its concentration and the duration of incubation in HepG2 hepatocarcinoma cells.
Furthermore, ROS overproduction and increased MDA levels may directly influence HCT 116 cell viability. In the present study, melatonin at a $10^{-6} \mathrm{M}$ concentration had pro-oxidant properties, which resulted in decreased HCT 116 cell viability (76\% of control, untreated cells). These results are concordant with the observations of other studies $(28,53)$. Roth et al $(53)$, also revealed that melatonin, at analogous experimental concentrations, resulted in decreased $\mathrm{PC}-12$ prostate cancer cell viability, as compared with the control cells $(85.5 \%$ of control). The antiproliferative effects of melatonin have also been investigated in numerous cell culture systems, including the growth of chick skeletal muscle cells (54), ME-180 human cervical cancer cells (55), AH 130 rat hepatoma cells (56), human melanoma cells (57), human benign (58) and malignant prostate cells (59), and ovarian carcinoma cells (29).

The pro-oxidant and growth inhibitory effects of melatonin may be explained by the increased levels of intracellular ROS, as well as the decreased antioxidant capacity exhibited in the melatonin-treated cells. These observations are concordant with the findings of other studies, which revealed that melatonin was able to stimulate the production of ROS in tumor cells $(60,61)$, resulting in apoptosis (62). Pirozhok et al (61) demonstrated that an analogous dose of melatonin $\left(10^{-6} \mathrm{M}\right)$ was able to inhibit the proliferation of PC-3 human prostate cells, but did not alter the viability of the DU-145 prostate cancer cell line. Furthermore, numerous studies have reported that antioxidants, such as melatonin, may enhance the cytotoxic effects of chemotherapeutic agents on cancer cells, depending on the dose, form and type of cancer (63). For instance, Kim et al (63), demonstrated that combined treatment of cisplatin with melatonin synergistically inhibited the viability of SK-OV-3 ovarian cancer cells in vitro. Conversely, melatonin exhibited a protective effect against cisplatin-induced cytotoxicity in OSEN normal ovarian epithelial cells. Furthermore, Lamson and Brignall (64) showed that treatment with melatonin increased survival time and tumor response in patients treated with tamoxifen, cisplatin and etoposide, thus suggesting that melatonin may increase the chemotherapeutic effect of these drugs (64). The modulation of cell signaling pathways by antioxidants may aid in the prevention of cancer by preserving normal cell cycle regulation, inhibiting tumor invasion and angiogenesis, inhibiting proliferation, inducing apoptosis and stimulating phase II detoxification enzyme activity (37). Previous findings by the authors of the present study demonstrated that another antioxidant, vitamin E ( $\alpha$-tockopherol), also induced antioxidant enzyme activity in AT478 carcinoma cells in vitro. AT478 cells subjected to the action of vitamin E were shown to be more resistant to exogenous oxidative stress, as compared with cells exposed solely to a magnetic field (65).

In conclusion, the present study demonstrated that ghrelin, leptin and melatonin have various affects on the antioxidant capacity of HCT 116 cells. Compared with the adipokines, treatment with melatonin increased ROS levels and decreased cellular viability of tested cells. The present study also had several limitations. The in vitro setting may not fully reflect the more complex assocaitions in organisms, as a whole, and therefore, the setting of the study may be kept in mind. It is possible that the result may not be similar to what is observed in living subjects 


\section{Acknowledgements}

The present study was supported by a grant from the Medical University of Silesia in Katowice (grant no. KNW-1-011/N/1/0).

\section{References}

1. Housa D, Housová J, VernerováZ and Haluzík M: Adipocytokines and cancer. Physiol Res 55: 233-244, 2006.

2. Pischon T, Nöthlings U and Boeing H: Obesity and cancer. Proc Nutr Soc 67: 128-145, 2008.

3. Mantovani G, Macciò A, Madeddu C, et al: Reactive oxygen species, antioxidant mechanisms and serum cytokine levels in cancer patients: Impact of an antioxidant treatment. J Cell Mol Med 6: 570-582, 2002.

4. Wiecek A, Kokot F, Chudek J and Adamczak M: The adipose tissue - a novel endocrine organ of interest to the nephrologist. Nephrol Dial Transplant 17: 191-195, 2002.

5. Kojima M, Hosoda H, Date Y, Nakazato M, Matsuo $H$ and Kangawa K: Ghrelin is a growth-hormone-releasing acylated peptide from stomach. Nature 402: 656-660, 1999.

6. van der Lely AJ, Tschöp M,Heiman ML and Ghigo E: Biological, physiological, pathophysiological, and pharmacological aspects of ghrelin. Endocr Rev 25: 426-457, 2004.

7. Suzuki H, Matsuzaki J and Hibi T: Ghrelin and oxidative stress in gastrointestinal tract. J Clin Biochem Nutr 48: 122-125, 2011.

8. He X-T, Fan X-M and Zha X-L: Ghrelin inhibits 5-fluorouracil-induced apoptosis in colonic cancer cells. J Gastroenterol Hepatol 26: 1169-1173, 2011

9. Nanzer AM, Khalaf S, Mozid AM, et al: Ghrelin exerts a proliferative effect on a rat pituitary somatotroph cell line via the mitogen-activated protein kinase pathway. Eur J Endocrinol 151: 233-240, 2004

10. Gnanapavan S, Kola B, Bustin SA, et al: The tissue distribution of the mRNA of ghrelin and subtypes of its receptor, GHS-R, in humans. J Clin Endocrinol Metab 87: 2988, 2002.

11. Tian PY and Fan XM: The proliferative effects of ghrelin on human gastric cancer AGS cells. J Dig Dis 13: 453-458, 2012.

12. Barazzoni R, Zanetti M, Semolic A, Cattin MR, Pirulli A, Cattin L and Guarnieri G: High-fat diet with acyl-ghrelin treatment leads to weight gain with low inflammation, high oxidative capacity and normal triglycerides in rat muscle. PLoS One 6: e26224, 2011.

13. Konturek PC, Brzozowski T, Pajdo R, et al: Ghrelin-a new gastroprotective factor in gastric mucosa. J Physiol Pharmacol 55 325-336, 2004.

14. El Eter E, Al Tuwaijiri A, Hagar $\mathrm{H}$ and Arafa M: In vivo and in vitro antioxidant activity of ghrelin: Attenuation of gastric ischemic injury in the rat. J Gastroenterol Hepatol 22: 1791-1799, 2007.

15. Zhang Y, Proenca R, Maffei M, Barone M, Leopold L and Friedman JM: Positional cloning of the mouse obese gene and its human homologue. Nature 372: 425-432, 1994

16. Aloulou N, Bastuji-Garin S, Le Gouvello S, et al: Involvement of the leptin receptor in the immune response in intestinal cancer. Cancer Res 68: 9413-9422, 2008.

17. Trayhurn P and Beattie JH: Physiological role of adipose tissue: White adipose tissue as an endocrine and secretory organ. Proc Nutr Soc 60: 329-339, 2001.

18. Watson AM, Poloyac SM, Howard G and Blouin RA: Effect of leptin on cytochrome P-450, conjugation, and antioxidant enzymes in the ob/ob mouse. Drug Metab Dispos 27: 695-700, 1999.

19. Yuan Y, Zhang J, Cai L, et al: Leptin induces cell proliferation and reduces cell apoptosis by activating c-myc in cervical cancer. Oncol Rep 29: 2291-2296, 2013.

20. Wu X, Yan Q, Zhang Z, Du G and Wan X: Acrp30 inhibits leptin-induced metastasis by downregulating the JAK/STAT3 pathway via AMPK activation in aggressive SPEC-2 endometrial cancer cells. Oncol Rep 27: 1488-1496, 2012.

21. Yoon K-W, Park S-Y, Kim J-Y, et al: Leptin-induced adhesion and invasion in colorectal cancer cell lines. Oncol Rep 31: 2493-2498, 2014.

22. Brydon L, Petit L, Delagrange P, Strosberg AD and Jockers R Functional expression of MT2 (Mel1b) melatonin receptors in human PAZ6 adipocytes. Endocrinology 142: 4264-4271, 2001.

23. Reiter RJ: Melatonin: Lowering the high price of free radicals. News Physiol Sci 15: 246-250, 2000.
24. Baydaş G, Erçel E, Canatan H, Dönder E and Akyol A: Effect of melatonin on oxidative status of rat brain, liver and kidney tissues under constant light exposure. Cell Biochem Funct 19: $37-41,2001$

25. Rodriguez C, Mayo JC, Sainz RM, Antolín I, Herrera F, Martín V and Reiter RJ: Regulation of antioxidant enzymes: A significant role for melatonin. J Pineal Res 36: 1-9, 2004.

26. Martín-Renedo J, Mauriz JL, Jorquera F, Ruiz-Andrés O, González P and González-Gallego J: Melatonin induces cell cycle arrest and apoptosis in hepatocarcinoma HepG2 cell line. J Pineal Res 45: 532-540, 2008.

27. Fan L-L, Sun G-P, Wei W, Wang Z-G, Ge L, Fu W-Z and Wang H: Melatonin and doxorubicin synergistically induce cell apoptosis in human hepatoma cell lines. World J Gastroenterol 16: 1473-1481, 2010.

28. Osseni RA, Rat P, Bogdan A, Warnet JM and Touitou Y: Evidence of prooxidant and antioxidant action of melatonin on human liver cell line HepG2. Life Sci 68: 387-399, 2000.

29. Petranka J, Baldwin W, Biermann J, Jayadev S, Barrett JC and Murphy E: The oncostatic action of melatonin in an ovarian carcinoma cell line. J Pineal Res 26: 129-136, 1999.

30. LeBel CP, Ischiropoulos $\mathrm{H}$ and Bondy SC: Evaluation of the probe 2',7'-dichlorofluorescin as an indicator of reactive oxygen species formation and oxidative stress. Chem Res Toxicol 5: 227-231, 1992.

31. Bułdak RJ, Polaniak R, Bułdak L, et al: Short-term exposure to $50 \mathrm{~Hz}$ ELF-EMF alters the cisplatin-induced oxidative response in AT478 murine squamous cell carcinoma cells. Bioelectromagnetics 33: 641-651, 2012.

32. Paglia DE and Valentine WN: Studies on the quantitative and qualitative characterization of erythrocyte glutathione peroxidase. J Lab Clin Med 70: 158-169, 1967.

33. Bułdak RJ, Bułdak $€$, Polaniak R, et al: Visfatin affects redox adaptative responses and proliferation in Me45 human malignant melanoma cells: An in vitro study. Oncol Rep 29: 771-778, 2013.

34. Paoletti F and Mocali A: Determination of superoxide dismutase activity by purely chemical system based on NAD $(\mathrm{P}) \mathrm{H}$ oxidation. Methods Enzymol 186: 209-220, 1990.

35. Aebi H: Catalase in vitro. Methods Enzymol 105: 121-126, 1984.

36. Ohkawa H, Ohishi $\mathrm{N}$ and Yagi K: Assay for lipid peroxides in animal tissues by thiobarbituric acid reaction. Anal Biochem 95: 351-358, 1979.

37. Anisimov VN, Popovich IG, Zabezhinski MA, Anisimov SV, Vesnushkin GM and Vinogradova IA: Melatonin as antioxidant, geroprotector and anticarcinogen. Biochim Biophys Acta 1757: 573-589, 2006.

38. Valko M, Leibfritz D, Moncol J, Cronin MTD, Mazur M and Telser J: Free radicals and antioxidants in normal physiological functions and human disease. Int J Biochem Cell Biol 39: 44-84, 2007.

39. Koda M, Sulkowska M, Kanczuga-Koda L, Surmacz E and Sulkowski S: Overexpression of the obesity hormone leptin in human colorectal cancer. J Clin Pathol 60: 902-906, 2007.

40. Aparicio T, Kotelevets L, Tsocas A, et al: Leptin stimulates the proliferation of human colon cancer cells in vitro but does not promote the growth of colon cancer xenografts in nude mice or intestinal tumorigenesis in Apc(Min/+) mice. Gut 54: 1136-1145, 2005.

41. Zhou J, Lei W, Shen L, Luo H-S and Shen Z-X: Primary study of leptin and human hepatocellular carcinoma in vitro. World J Gastroenterol 14: 2900-2904, 2008.

42. Catalano S, Marsico S, Giordano C, et al: Leptin enhances, via AP-1, expression of aromatase in the MCF-7 cell line. J Biol Chem 278: 28668-28676, 2003

43. Chang S, Hursting SD, Contois JH, et al: Leptin and prostate cancer. Prostate 46: 62-67, 2001.

44. Gonzalez RR, Cherfils S, Escobar M, et al: Leptin signaling promotes the growth of mammary tumors and increases the expression of vascular endothelial growth factor (VEGF) and its receptor type two (VEGF-R2). J Biol Chem 281: 26320-26328, 2006.

45. Yamagishi SI, Edelstein D, Du XL, Kaneda Y, Guzmán M and Brownlee M: Leptin induces mitochondrial superoxide production and monocyte chemoattractant protein-1 expression in aortic endothelial cells by increasing fatty acid oxidation via protein kinase A. J Biol Chem 276: 25096-25100, 2001.

46. Xu F-P, Chen M-S, Wang Y-Z, Yi Q, Lin S-B, Chen AF and Luo J-D: Leptin induces hypertrophy via endothelin-1-reactive oxygen species pathway in cultured neonatal rat cardiomyocytes. Circulation 110: 1269-1275, 2004. 
47. Zwirska-Korczala K, Adamczyk-Sowa M, Sowa P, et al: Role of leptin, ghrelin, angiotensin II and orexins in 3T3 L1 preadipocyte cells proliferation and oxidative metabolism. J Physiol Pharmacol 58 (Suppl 1): 53-64, 2007.

48. Balasubramaniyan V, Shukla R, Murugaiyan G, Bhonde RR and Nalini N: Mouse recombinant leptin protects human hepatoma HepG2 against apoptosis, TNF-alpha response and oxidative stress induced by the hepatotoxin-ethanol. Biochim Biophys Acta 1770: 1136-1144, 2007.

49. Li WG, Gavrila D, Liu X, et al: Ghrelin inhibits proinflammatory responses and nuclear factor-kappaB activation in human endothelial cells. Circulation 109: 2221-2226, 2004.

50. Valko M, Rhodes CJ, Moncol J, Izakovic M and Mazur M: Free radicals, metals and antioxidants in oxidative stress-induced cancer. Chem Biol Interact 160: 1-40, 2006.

51. Tong $\mathrm{X}-\mathrm{X}, \mathrm{Wu} \mathrm{D}$, Wang $\mathrm{X}$, et al: Ghrelin protects against cobalt chloride-induced hypoxic injury in cardiac H9c2 cells by inhibiting oxidative stress and inducing autophagy. Peptides 38: 217-227, 2012.

52. Kheradmand A, Alirezaei M and Birjandi M: Ghrelin promotes antioxidant enzyme activity and reduces lipid peroxidation in the rat ovary. Regul Pept 162: 84-89, 2010.

53. Roth JA, Rosenblatt T, Lis A and Bucelli R: Melatonin-induced suppression of PC12 cell growth is mediated by its Gi coupled transmembrane receptors. Brain Res 919: 139-146, 2001.

54. Lamosová D, Zeman M and Juráni M: Influence of melatonin on chick skeletal muscle cell growth. Comp Biochem Physiol C Pharmacol Toxicol Endocrinol 118: 375-379, 1997.

55. Chen LD, Leal BZ, Reiter RJ, et al: Melatonin's inhibitory effect on growth of ME-180 human cervical cancer cells is not related to intracellular glutathione concentrations. Cancer Lett 91: 153-159, 1995.

56. Cini G, Coronnello M, Mini E and Neri B: Melatonin's growth-inhibitory effect on hepatoma $\mathrm{AH} 130$ in the rat. Cancer Lett 125: 51-59, 1998
57. Roberts JE, Wiechmann AF and Hu DN: Melatonin receptors in human uveal melanocytes and melanoma cells. J Pineal Res 28: $165-171,2000$.

58. Gilad E, Laudon M, Matzkin H, et al: Functional melatonin receptors in human prostate epithelial cells. Endocrinology 137: 1412-1417, 1996.

59. Lupowitz $\mathrm{Z}$ and Zisapel N: Hormonal interactions in human prostate tumor LNCaP cells. J Steroid Biochem Mol Biol 68: 83-88, 1999.

60. Dziegiel P, Podhorska-Okolow M, Surowiak P, Ciesielska U, Rabczynski J and Zabel M: Influence of exogenous melatonin on doxorubicin-evoked effects in myocardium and in transplantable Morris hepatoma in rats. In Vivo 17: 325-328, 2003.

61. Pirozhok I, Meye A, Hakenberg OW, Fuessel S and Wirth MP: Serotonin and melatonin do not play a prominent role in the growth of prostate cancer cell lines. Urol Int 84: 452-460, 2010.

62. Jang SS, Kim WD and Park W-Y: Melatonin exerts differential actions on $\mathrm{X}$-ray radiation-induced apoptosis in normal mice splenocytes and Jurkat leukemia cells. J Pineal Res 47: 147-155, 2009.

63. Kim J-H, Jeong S-J, Kim B, Yun S-M, Choi Y and Kim S-H: Melatonin synergistically enhances cisplatin-induced apoptosis via the dephosphorylation of ERK/p90 ribosomal S6 kinase/heat shock protein 27 in SK-OV-3 cells. J Pineal Res 52: 244-252, 2012.

64. Lamson DW and Brignall MS: Antioxidants in cancer therapy; their actions and interactions with oncologic therapies. Altern Med Rev 4: 304-329, 1999.

65. Polaniak R, Bułdak RJ, Karoń M, et al: Influence of an extremely low frequency magnetic field (ELF-EMF) on antioxidative vitamin E properties in AT478 murine squamous cell carcinoma culture in vitro. Int J Toxicol 29: 221-230, 2010. 